\title{
PENGEMBANGAN MULTIMEDIA DRILL AND PRACTICE UNTUK MENINGKATKAN KEMAMPUAN VOCABULARY BAHASA JEPANG
}

\author{
Rani Vita Sari, Sulton, Yerry Soepriyanto \\ Jurusan Teknologi Pendidikan, Fakultas Ilmu Pendidikan, Universitas Negeri Malang \\ Jalan Semarang 5 Malang 65145 0341-574700 \\ ranivitasari1@gmail.com
}

Article History

Received:28 Mei 2020, Accepted: 18 Januari 2021, Published: 26 Februari 2021

\begin{abstract}
Abstrak
Tujuan dari penelitian pengembangan ini yaitu untuk menghasilkan suatu produk berupa multimedia drill and practice yang layak digunakan dan juga valid dalam meningkatkan kemampuan kosakata bahasa Jepang. Penelitian pengembangan ini termasuk dalam jenis penelitian dan pengembangan (Research and Development) Lee dan Owens. Pada penelitian pengembangan multimedia drill and practice ini menghasilkan produk dalam kriteria valid/layak digunakan dengan hasil rata-rata yang diperoleh dari ahli media sebesar 3,7, dari ahli materi 3,8, dan hasil uji coba siswa sebesar 3,88.
\end{abstract}

Keyword: Pengembangan; Multimedia, Drill and practice

\begin{abstract}
The purpose of this development research is to produce a product in the form of multimedia drill and practice that is feasible to use and is also valid in improving the ability of Japanese vocabulary. Research and development are included in the type of research and development (Research and Development) Lee and Owens. In this multimedia development research, the drill and practice product produced a valid criteria / feasible to use with the average results obtained from media experts at 3,7, from material experts 3,8, and the results of student trials 3,88.
\end{abstract}

Keyword: Development; Interactive Multimedia, Drill and practice. 


\section{PENDAHULUAN}

Pendidikan didefinisikan sebagai salah satu aspek yang penting bagi kehidupan setiap orang. Pada dasarnya pendidikan yang dimaksud memiliki tujuan untuk meningkatkan kemampuan yang dimiliki oleh setiap orang sehingga dapat menghadapi segala tantangan dan perubahan yang terjadi dalam kehidupan. Sementara itu (Dimyati \& Mujiono, 2009) mengatakan "Pendidikan merupakan kegiatan interaksi. Dalam kegiatan interaksi tersebut pendidik atau guru bertindak mendidik siswa. Tindakan mendidik tersebut bertujuan pada perkembangan siswa menjadi mandiri”. Menurut (Undang-Undang Republik Indonesia, 1989) yang menyatakan bahwa "Pendidikan merupakan usaha sadar untuk menyiapkan siswa melalui kegiatan bimbingan, pembelajaran dan latihan bagi perannya di masa yang akan datang". Pendidikan yang berkualitas tentu didapat dari sumber daya manusia yang baik. Maka dari itu diperlukannya pengembangan di bidang pendidikan sehingga mutu pendidikan di Indonesia dapat menjadi lebih baik dari masa ke masa.

Pada dasarnya pembelajaran yaitu adanya interaksi antara siswa dengan guru yang menggunakan berbagai macam sumber belajar dalam proses pembelajaran. Menurut (Rusman, 2012) pembelajaran yaitu proses interaksi yang melibatkan guru dan juga siswa, baik secara langsung seperti aktivitas tatap muka maupun secara tidak langsung yang menggunakan media pembelajaran. Pembelajaran yang maksimal akan menjadi suatu keberhasilan apabila ditunjang oleh minat belajar siswa dan kreatifitas seorang guru. Seiring berkembangnya teknologi yang semakin pesat maka kualitas pendidikan dituntut untuk mengikuti perkembangan teknologi yang ada pada masa sekarang. Peranan komputer sebagai media pendukung menjadi sumber utama pembelajaran di sekolah. (Rusman, 2012) juga mengutarakan bahwa "Penggunaan komputer dalam pembelajaran memungkinkan berlangsungnya proses pembelajaran secara individual dengan menumbuhkan kemandirian dalam proses belajar sehingga siswa akan mengalami proses yang jauh lebih bermakna dibandingkan dengan pembelajaran konvensional". Beberapa penyebab kurangnya minat belajar siswa diantaranya adalah proses penyampaian yang dirasa kurang menarik dan juga membosankan. Dalam setiap pembelajaran seperti bahasa, guru selalu menggunakan metode yang masih terpusat di guru saja dan hal tersebut dapat membuat siswa bosan karena metode yang digunakan monoton.

Pengembangan yang dilakukan bahwa selain LKS juga guru yang masih berperan menjelaskan materi menggunakan PPT. Penggunaan media pembelajaran berupa buku paket maupun lks semakin lama membuat siswa merasa cepat bosan sehingga malas mengikuti pembelajaran (Educatio, 2014). Penggunaan media berupa lks dan buku paket masih digunakan oleh guru dalam mengajar tidak hanya materi di sekolah tetapi juga latihan soal. Media pembelajaran bersifat komplemen atau pelengkap diharapkan dapat membantu proses pembelajaran yang bersifat monoton menjadi bervariasi dan menyenangkan. Dalam penelitian pengembangan (Ramadhan et al., 2015) menyebutkan penggunaan media mbertujuan memberikan motivasi kepada siswa. Suatu media dikatakan baik jika media tersebut dapat membuat siswa aktif dalam pembelajaran, serta dapat membantu siswa untuk melaksanakan praktik yang benar juga umpan balik. Hal tersebut dapat dilakukan melalui pembelajaran berbasis multimedia drill and practice.

Tidak semua materi dapat ditampilkan melalui media pembelajaran, hal tersebut dapat dilakukan melalui pembelajaran berbasis multimedia drill and practice. Pembelajaran berbasis multimedia secara sederhana merupakan suatu kegiatan yang memanfaatkan komputer dalam pembelajaran dengan menggabungkan teks, grafik, audio, video, animasi dengan melakukan kombinasi link dan tools untuk interaksi bagi pengguna. Melalui drill and practice juga akan ditanamkan kebiasaan tertentu dalam bentuk latihan berulang. Dalam hal ini siswa diharuskan untuk aktif dalam memecahkan masalah berbentuk latihan soal. Drill and practice sendiri berpusat pada latihan berulang sehingga siswa mampu memahami materi yang diajarkan sebelumnya. 
Dalam pengembangan (Pacol \& Patacsil, 2018) sistem pembelajaran yang dilakukan secara tradisional telah trbukti bahwa kurang mampu memberikan hasil maksimal terhadap siswa, maka pendekatan menggunakan drill and ractice paling cocok dijadikan perantara pembelajaran. Drill and practice sendiri berpusat pada latihan berulang sehingga siswa mampu memahami materi yang telah diajarkan. Selain itu cara belajar yang berulang membuat siswa akan lebih mudah mempelajari materi seperti vocabulary atau kosakata bahasa Jepang serta beberapa latihan-latihan soal yang dikemas dalam bentuk multimedia yang menarik. Pembelajaran menggunakan media berupa drill and practice biasanya digunakan pada materi berhitung dan menghafal bahasa asing berhubungan dengan vocabulary. Minat baca siswa menjadi menurun terutama pada materi pembelajaran bahasa. Sehingga penggunaan media drill and practice cocok diaplikasikan dalam pembelajaran bahasa asing. Mata pelajaran bahasa Jepang merupakan salah satunya. Materi bahasa Jepang sendiri masih belum banyak diminati oleh siswa, dan melalui multimedia pembelajaran drill and practice siswa dapat belajar materi pada bahasa asing seperti bahasa Jepang dengan lebih mudah dan menyenangkan sehingga siswa tidak merasa bosan. Selain itu cara belajar yang berulang membuat siswa akan lebih mudah mempelajari materi seperti vocabulary atau kosakata bahasa Jepang serta beberapa latihan-latihan soal yang dikemas dalam bentuk multimedia yang lebih menarik.

Dalam hal komputerisasi drill and practice digunakan terutama untuk praktik serta proses dalam pembelajaran itu sendiri. Hal tersebut berlaku pada semua jenis pembelajaran, dengan asumsi bahwa pada panduan awal drill and practice yang digunakan telah akurat (Pacol \& Patacsil, 2018). Pada proses pembelajaran bahasa Jepang siswa cenderung sulit mengingat materi pembelajaran yang sudah diajarkan sebelumnya. Berdasarkan permasalahan tersebut, dengan digunakannya media pembelajaran berupa multimedia drill and practice tersebut diharapkan dapat digunakan dalam proses pembelajaran serta mampu menjadi solusi masalah menurunya minat baca Siswa Menengah Atas khususnya pada mata pelajaran bahasa asing, dalam hal ini yaitu ada pada bahasa Jepang. Tujuan pengembangan ini dapat menghasilkan sebuah produk multimedia drill and practice Bahasa Jepang dasar pada pokok bahasan Salam Sapaan, yaitu media berupa aplikasi sederhana yang menarik perhatian siswa dan mudah dioperasikan oleh siswa selama proses pembelajaran serta memberikan solusi terhadap masalah menurunnya minat baca dan kemampuan kosakata siswa jurusan bahasa di SMA Negeri 9 Malang.

\section{Multimedia}

Multimedia berasal dari bahasa latin yang artinya terdapat pada kata multi yang berarti banyak, dan medium yang artinya adalah sesuatu yang digunakan dalam penyampaian pesan tertentu. Multimedia juga diartikan sebagai suatu hal yang melibatkan beberapa jenis media dalam proses pembelajaran. Penggunaan dan penggabungan beberapa media yang berbeda dan informasinya disampaikan ke dalam bentuk teks, grafik, audio, video, animasi. (Mayer, 2009) mengartikan multimedia sebagai penampil materi dalam bentuk kalimat verbal maupun non-verbal.

Adapun pengertian yang dikemukakan oleh (Rusman, 2011) berpendapat bahwa multimedia berarti memanfaatkan komputer untuk membuat serta menggabungkan teks, grafik, audio,video, animasi dengan link (tautan) dan tools untuk interaksi antara pengguna dan multimedia. Selain itu (Binanto, 2010) menjelaskan bahwa multimedia dibagi menjadi beberapa jenis diantaranya yaitu multimedia Interaktif yang mana sebagai seorang pengguna dapat mengotrol apa saja dan kapan sebuah elemen multimedia dapat ditampilkan. Multimedia juga memiliki arti konsep teknologi baru pada saat ini, karena informasi didalamnya berbentuk teks, gambar, audio, animasi, dan video digabungkan dalam komputer dan selanjutnya disimpan, diproses lalu ditampilkan secara interaktif. Melalui gabungan antara elemen multimedia tersebut, maka hal tersebut akan menjadi suatu informasi yang dapat diterima oleh pengguna melalui indera penglihatan dan indera pendengaran dalam bentuk multimedia.

Pembelajaran berbasis multimedia dapat diartikan sebagai kegiatan pembelajaran yang memungkinkan bagi pengguna untuk dapat berinteraksi dan berkomunikasi. (Rusman, 2012:140) 
Pembelajaran berbasis multimedia yaitu kegiatan pembelajaran yang memanfaatkan media komputer sebagai alat untuk menggabungkan teks, audio, video dengan link dan tools yang akan memungkinkan penggunanya untuk dapat melakukan interaksi, navigasi, berkreasi, serta komunikasi. Pembelajaran berbasis multimedia sendiri difungsikan sebagai salah satu upaya peningkatan mutu belajar dalam proses pembelajaran. "Bahan-bahan audio-visual dapat memberikan banyak manfaat asalkan guru juga berperan aktif dalam suatu proses pembelajaran" (Dale \&Edgar, 1969). Berdasarkan pernyataan tersebut dapat dikatakan bahwa penggunaan multimedia pembelajaran berfungsi sebagai akses yang memudahkan proses pembelajaran serta membantu siswa untuk dapat berinteraksi secara langsung dengan multimedia. Multimedia sendiri memiliki kegunaan berdasarkan jenisnya menurut yang disampaikan oleh (Ariani, Niken. \& Haryanto, 2010) yaitu yang pertama pada jenis multimedia presentasi pembelajaran adalah media guru dalam proses pembelajaran di kelas, dan berdasarkan jenis yang kedua yaitu multimedia pembelajaran mandiri yang mana harus mampu memadukan pengetahuan tertulis yang tersedia di buku atau artikel karena sebagai pengganti peran guru dalam latihan dan simulasi pemecahan masalah.

Dalam penelitian pengembangan yang dilakukan multimedia sendiri digunakan sebagai salah satu cara atau upaya peningkatan kualitas dan mutu belajar selama proses pembelajaran (Adiwisastra, 2015). "Bahan-bahan audio-visual dapat memberikan banyak manfaat asalkan guru juga berperan aktif dalam suatu proses pembelajaran" Dale (1969:180. Dalam hal ini, multimedia juga memiliki kelebihan tersendiri. Kelebihan multimedia interaktif menurut (Smaldino, S.E., Lowther D.L., \& Rusell, 2011) diantaranya yaitu : (1) Siswa berkemungkinan mengendalikan hasil belajar secara individu, (2) Partisipasi siswa meningkat, (3) Manajemen informasi teks, grafis, audio, dan video dapat dikelola. Selain kelebihan ada pula kelemahan yang dimiliki multimedia, seperti design yang buruk akan membuat pengguna kebingungan sehingga pesan pada multimedia tidak tersampaikan dengan sempurna, bagi orang yang memiliki keterbatasan akan menjadi suatu kendala.

\section{Drill and practice}

Drill and practice secara sederhana memberikan penekanan kepada siswa untuk dapat menguasai materi melalui latihan dan praktik secara berkala atau berulang. Drill and practice dapat didefinisikan sebagai suatu metode pengajaran yang ditandai dengan sistematis pengulangan konsep atau materi sebelumnya. Menurut Alessi dan Trollip (1985:92) "many people believe drills are useful only in limited areas such as arithmetic and spelling". Pembelajaran menggunakan media berupa drill and practice pada hakikatnya digunakan pada materi pembelajaran berhitung dan menghafal bahasa asing dan peningkatan vocabulary. Sehingga penggunaan media drill and practice cocok digunakan dalam pembelajaran bahasa Jepang. Pembelajaran bahasa Jepang merupakan suatu pembelajaran yang pada umumnya banyak ditemukan pada pendidikan di Indonesia khususnya pada jenjang Sekolah Menengah Atas jurusan bahasa maupun sebagai lintas minat siswa. Beberapa pokok bahasan atau materi yang diterima oleh siswa diantaranya yaitu salam sapaan dan ungkapan, lingkungan sekolah, anggota keluarga, lingkungan rumah, pekerjaan, huruf Jepang, budaya Jepang, benda-benda di lingkungan sekitar, dan lain-lain. Bahasa Jepang sendiri merupakan bahasa nasional yang digunakan sehari-hari oleh masyarakat di Negara Jepang. Beberapa sekolah di Indonesia sendiri masih banyak yang memasukkan materi bahasa Jepang sebagai salah satu mata pelajaran wajib. Hal tersebut dikarenakan belajar bahasa Jepang tidak hanya mengetahui tentang arti kata bahasa itu sendiri tetapi juga belajar tentang budaya masyarakat Jepang.

Berdasarkan penelitian pengembangan yang telah dilakukan oleh (Candra, 2014) model pembelajaran drill and practice merupakan proses latihan berulang terhadap suatu hal hingga tercapainya tujuan. Proses belajar tersebut memiliki sifat kompleks karena terjadi secara berulang-ulang. Menyajikan berbagai latihan-latihan soal dan jawaban serta umpan balik sebagai pembetulan. Sedangkan kegunaan dari drill and practice dapat memberikan motivasi kepada siswa dalam proses 
pembelajaran, memperkaya kosakata serta keterampilan siswa dalam belajar. Dalam hal ini, mata pelajaran bahasa Jepang sendiri terdapat banyak materi didalamnya, salah satunya yaitu pada pokok bahasan Salam Sapaan yang merupakan materi dasar atau yang biasa dipelajari pada pertama kali melakukan pembelajaran bahasa Jepang. Yang ada dalam materi atau pokok bahasan tersebut adalah bagaimana salam sapaan yang digunakan apabila bertemu dengan seseorang ketika pagi, siang, dan malam hari kepada orang lain dalam menggunakan kosakata bahasa Jepang. Dalam hal ini multimedia tersebut diciptakan guna untuk melatih siswa dalam menambah kosa kata atau dapat dikatakan juga menghafalkan beberapa kosa kata dalam bahasa Jepang khususnya dalam pokok bahasan salam sapaan yang dapat digunakan sehari-hari. Dengan cara melatih siswa secara terus menerus atau brulang maka akan membuat siswa dapat menghafal dan terbiasa dengan kosa kata baru sehingga mereka akan merasa nyaman saat menggunakan kosa kata baru tersebut dalam proses pembelajaran.

Dalam penelitiannya, (Hussein, 2015) metode drill and practice cocok untuk menyelesaikan masalah dan latihan untuk mata pelajaran seperti matematika, statistik, fisika, dan bahasa. Metode ini digunakan agar siswa : (1) Mempunyai keterampilan motorik seperti menghafalkan kosakata, (2) Mengembangkan kecakapan intelek, seperti hitung menghitung dalam matematika atau ilmu kimia, (3) Mempunyai kemampuan menghubungkan keadaan dengan hal lainnya. Adapun beberapa penyebab kurangnya minat baca pada siswa diantaranya yaitu proses penyampaian yang monoton dapat menimbulkan siswa merasa bosan. Di dalam pembelajaran bahasa asing tidak ada variasi-variasi belajar yang inovatif.

Dalam penelitian pengembangan yang dilakukan oleh (Widodo \& Pd, 2017) Pelaksanaan metode Drill and practice dapat mencapai keaktifan siswa jika dibantu dengan peralatan yang sesuai dengan kebutuhan. Dalam Penelitian pengembangan kali ini subjek ujicoba merupakan siswa kelas X SMA Negeri 9 Malang. Yang membedakan penelitian pengembangan ini dengan penelitian engembangan sebelumnya yaitu terdapat pada multimedia drill and ractice yang digunakan. Sebelumnya belum pernaha ada multimedia drill and practice dengan tema bahasa Jepang, karena setelah melakukan observasi di sekolah menunjukkan bahwa pembelajaran bahasa asing khususnya bahasa Jepang menunjukkan bahwa kebanyakan siswa tidak terlalu tertarik dengan materi bahasa Jepang sehingga akan mempengaruhi hasil belajar siswa. Maka dari itu multimedia drill and practice bahasa Jepang ini sangat diperlukan dalam membantu siswa. (Ampuch et al., 2014) Materi elektronik adalah bagian dari materi yang menarik perhatian para peserta, karena media ini memiliki kemampuan untuk menghadirkan dengan menggunakan multimedia seperti karakter, teks, grafik, dan bahasa isyarat.

Pengembangan multimedia drill and practice ini sendiri difokuskan terhadap kuis atau latihan soal pada mata pelajaran Bahasa Jepang dasar yang sudah diberikan pada semester sebelumnya oleh guru. Materi yang terdapat pada multimedia drill and practice berupa kuis mengenai pembelajaran dasar bahasa Jepang salam sapaan dan ungkapan. Yang bertujuan untuk mengetahui sejauh mana siswa mengingat materi yang tidak asing bagi mereka dalam bentuk multimedia yang dikemas secara menarik. Materi bahasa Jepang sendiri masih belum banyak diminati oleh siswa, dan melalui multimedia pembelajaran drill and practice siswa dapat belajar materi pada bahasa asing seperti bahasa Jepang dengan lebih mudah dan menyenangkan sehingga siswa tidak merasa bosan. Selain itu cara belajar yang berulang membuat siswa akan lebih mudah mempelajari materi seperti vocabulary atau kosakata bahasa Jepang serta beberapa latihan-latihan soal yang dikemas dalam bentuk multimedia yang menarik. Berdasarkan paparan diatas maka penggunaan multimedia dalam proses pembelajaran diharapkan dapat meningkatkan kemampuan belajar siswa dalam pembelajaran bahasa asing seperti bahasa Jepang dengan menggunakan media pembelajaran berupa multimedia drill and practice. Karena pada proses pembelajaran bahasa Jepang tidak sedikit siswa yang cenderung sulit mengingat materi sebelumnya khususnya pada pembelajaran bahasa asing yang disebabkan karena sulitnya menghafal dan mengingat 
kosakata, serta mengartikannya dalam bahasa Indonesia, maupun dalam hal pengucapannya. Maka dari itu dilakukannya penelitian pengembangan ini..

\section{METODE}

Untuk dapat mencapai tujuan pengembangan perlu ditetapkan suatu metode pengembangan. Dalam proses pengembangan media Multimedia Drill and practice ini menggunakan model dari pengembangan Lee dan Owens. Penggunaan model penelitian pengembangan ini dipilih karena pada pengembangan multimedia ini membutuhkan banyak analisis. Pada model pengembangan ini memiliki dua tahap analisis yaitu analisis kebutuhan dan analisis awal hingga akhir.

Penelitian pengembangan ini dilaksanakan pada semester genap tahun ajaran 2019/2020. Dengan objek penelitian media multimedia drill and practice mata pelajaran bahasa Jepang yang dikembangkan. Subjek dalam penelitian ini adalah siswa kelas X SMA Negeri 9 Malang. Dalam model penelitian pengembangan ini dapat dilakukan pula evaluasi pada setiap tahap pengembangan, sehingga kekurangan produk dapat segera diketahui, serta adanya efektifitas waktu yang dapat dijangkau untuk mengembangkan multimedia. Dalam model penelitian oleh seorang (Lee. W. W \& Owens, 2004) memiliki beberapa tahapan yang perlu dilakukan, yaitu : (1) analisis, (2) desain, (3) implementasi/ pengembangan, (4) evaluasi.

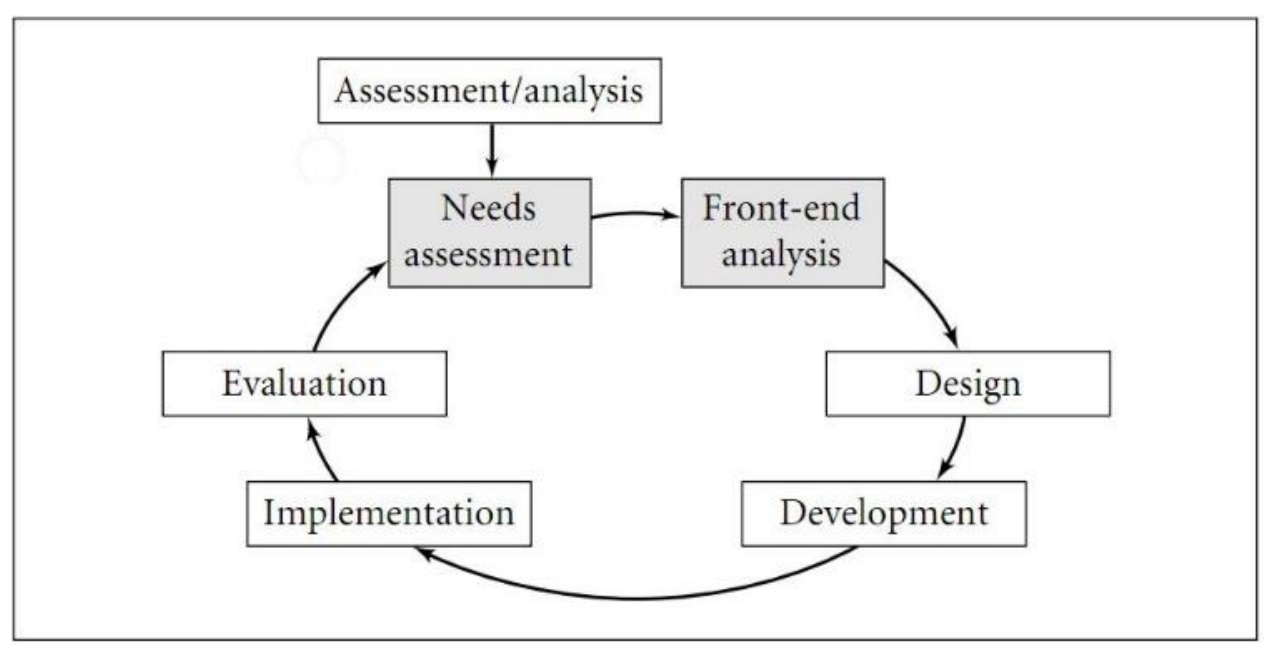

Gambar 1. Model Pengembangan William W.Lee dan Diana L. Owens (2004)

\section{HASIL}

Data validasi produk pengembangan multimedia drill and practice ini diperoleh melalui hasil penilaian validasi oleh ahli media dan ahli materi. Data validasi produk pengembangan multimedia drill and practice yang diperoleh dalam penelitian ini terdapat instrumen pengumpulan data yang digunakan pada penelitian pengembangan multimedia drill and practice bahasa Jepang yaitu dengan menggunakan pendekatan kuantitatif berupa angket (questionnaire).

Dalam penelitian pengembangan multimedia drill and practice kali ini jenis angket yang digunakan yaitu jenis angket terbuka, merupakan angket dengan sistem menjawab tidak menggunakan pilihan ganda pada jawaban, sehingga seorang responden atau narasumber dapat dengan leluasa mengisi pertanyaan dalam angket tersebut tanpa dibatasi dengan alternatif jawaban dari angket tersebut. Dan dalam implementasi produk multimedia drill and practice untuk meningkatkan kemampuan vocabulary bahasa Jepang ini di peroleh beberapa hasil, dalam tahapan pertama yaitu analisis, penelitian pengembangan yang digunakan untuk mencari permasalahan dan yang dibutuhkan oleh siswa Jurusan Bahasa Kelas X SMAN 9 Malang yaitu ada dalam kemampuan kosakata pembelajaran bahasa Jepang pada siswa yang lambat dan menyebabkan nilai pelajaran siswa menurun. Kemudian desain meliputi rangkaian storyboard produk multimedia drill and practice 


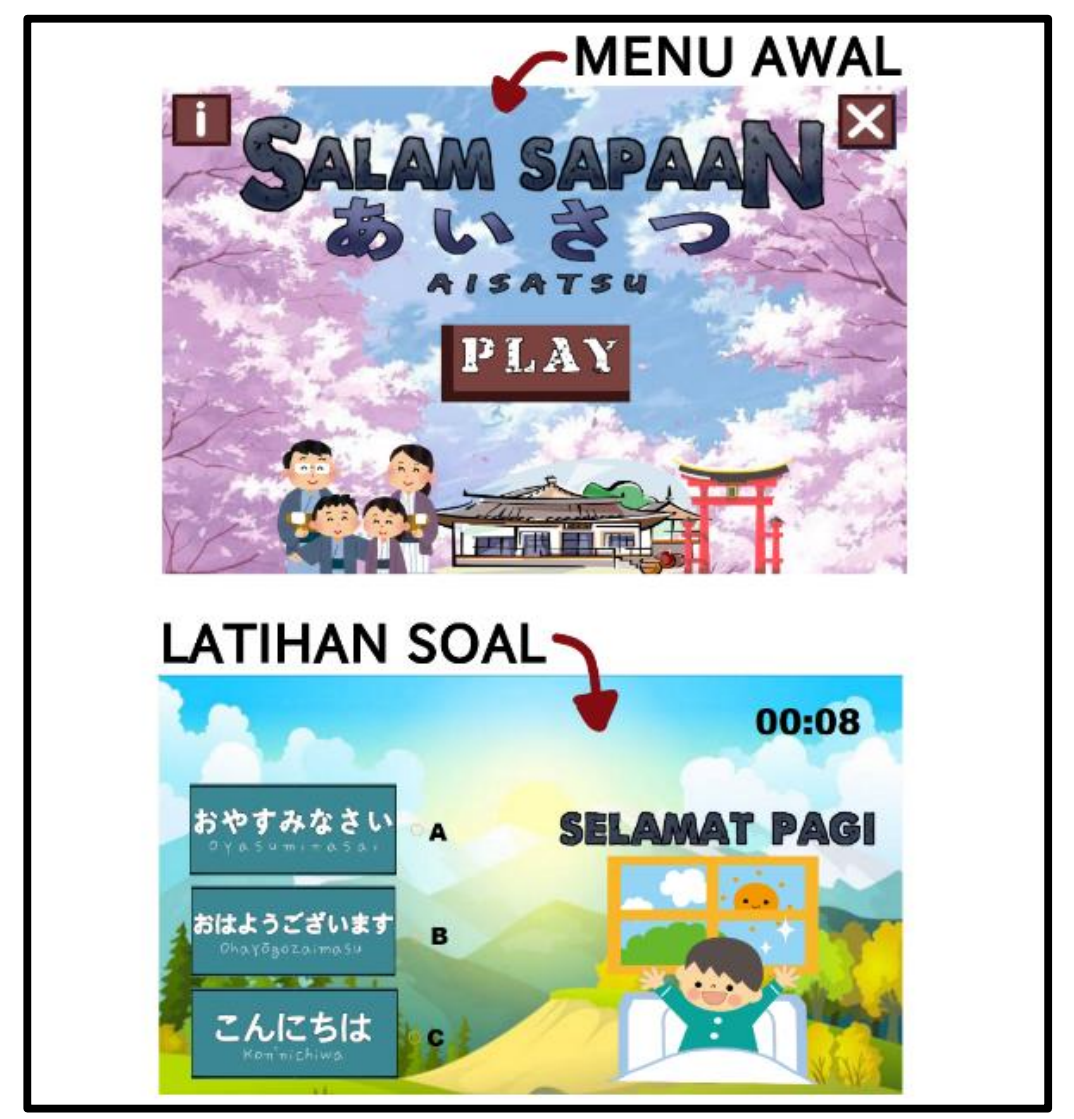

Gambar 2. Tampilan storyboard multimedia drill and practice

Selanjutnya ada tahap development \& implementation yang mana dilakukan validasi ahli media dan validasi ahli materi terhadap hasil Pengembangan Multimedia Drill and practice untuk Meningkatkan Kemampuan Kosakata Bahasa Jepang. Setelah produk dinyatakan valid oleh ahli, selanjutnya diujicobakan kepada siswa. Dalam angket validasi ahli media dan ahli materi terdiri dari 15 butir dengan niai maksimal empat dan nilai terendah satu.

\section{Tabel 1. Kriteria kelayakan ahli media dan ahli materi}

\begin{tabular}{cccc}
\hline Interval Nilai & Rata-rata & Kualifikasi & Ekuivalen \\
\hline $\mathbf{4 6}-\mathbf{6 0}$ & $3,1-4$ & Valid & Layak \\
$\mathbf{3 1}-\mathbf{4 5}$ & $2,1-3$ & Cukup Valid & Cukup Layak \\
$\mathbf{1 5}-\mathbf{3 0}$ & $1-2$ & Tidak Valid & Tidak Layak \\
\hline
\end{tabular}

Berdasarkan hasil dari Ahli media, jumlah keseluruhan yang didapat mencapai 56 dari 60 yang diharapkan dan nilai rata-rata jawaban keseluruhan mencapai 3,7. Sehingga diperoleh hasil valid dan layak digunakan. Sementara berdasarkan hasil dari ahli materi, jumlah keseluruhan yang didapat 57 dari 60 yang diharapkan dengan nilai rata-rata keseluruhan mencapai 3,8. Sehingga diperoleh hasil valid dan layak untuk digunakan. Selain dari pernyataan, juga diperoleh komentar dan saran dari ahli mengenai Pengembangan Multimedia Drill and practice bahasa Jepang ini. Dari beberapa komentar dan saran yang diperoleh diantaranya : Menambah audio pada pembuka media, media yang ditampilkan cukup menarik dan mudah dimengerti, ada dua soal yang harus direvisi yaitu kata Ohayou dan Konnichiwa. 


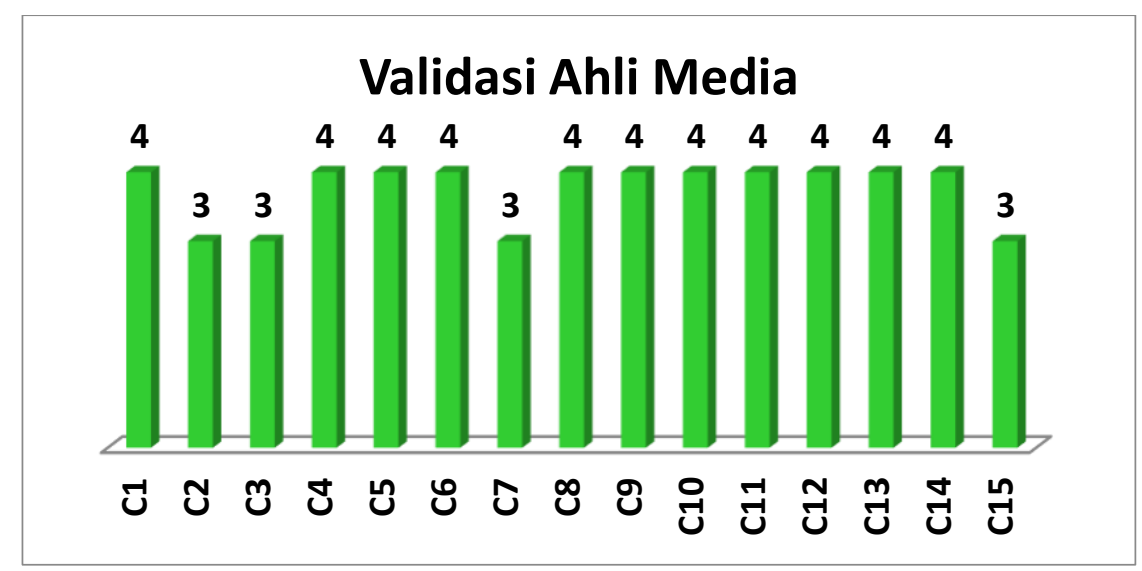

Gambar 3. Hasil Validasi Ahli Media

Dalam uji coba suatu produk multimedia memiliki tujuan untuk mengumpulkan data yang fungsinya digunakan untuk mengetahui tingkat keefektifan serta kevalidan dari multimedia drill and practice bahasa Jepang. Hasil uji coba kelompok kecil :

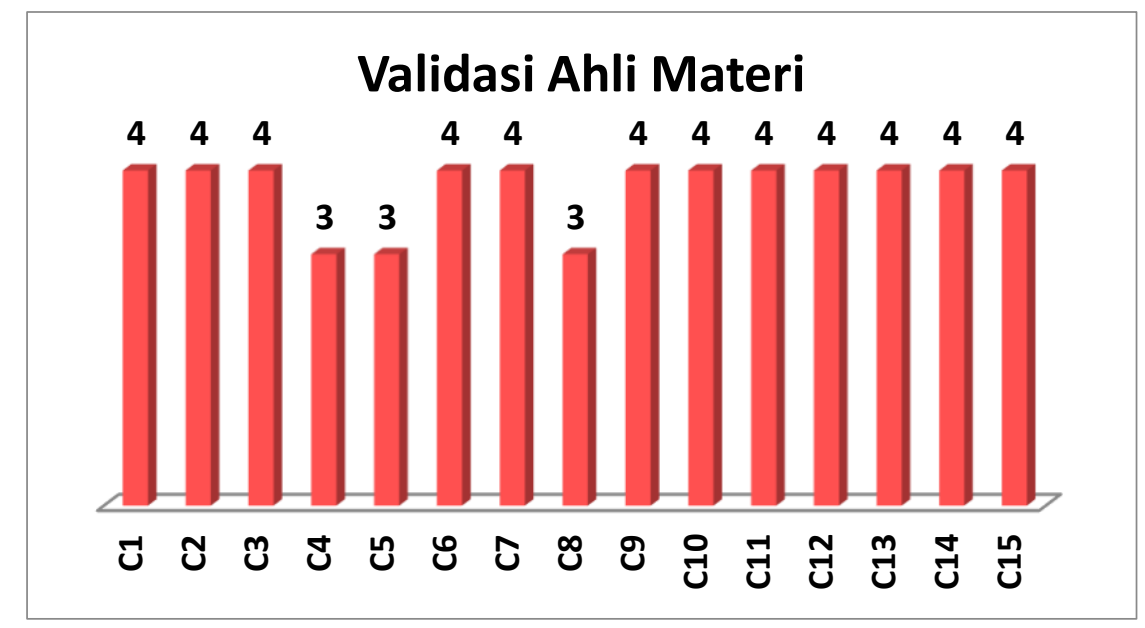

Gambar 4. Hasil Validasi Ahli Materi

Uji Coba dilakukan pada pengguna. Pada uji coba kelompok kecil diperoleh rata-rata keseluruhan jawaban audien berjumlah 3,88 dari 4 yang diharapkan. Sehingga multimedia drill and practice bahasa Jepang ini dinyatakan layak/valid

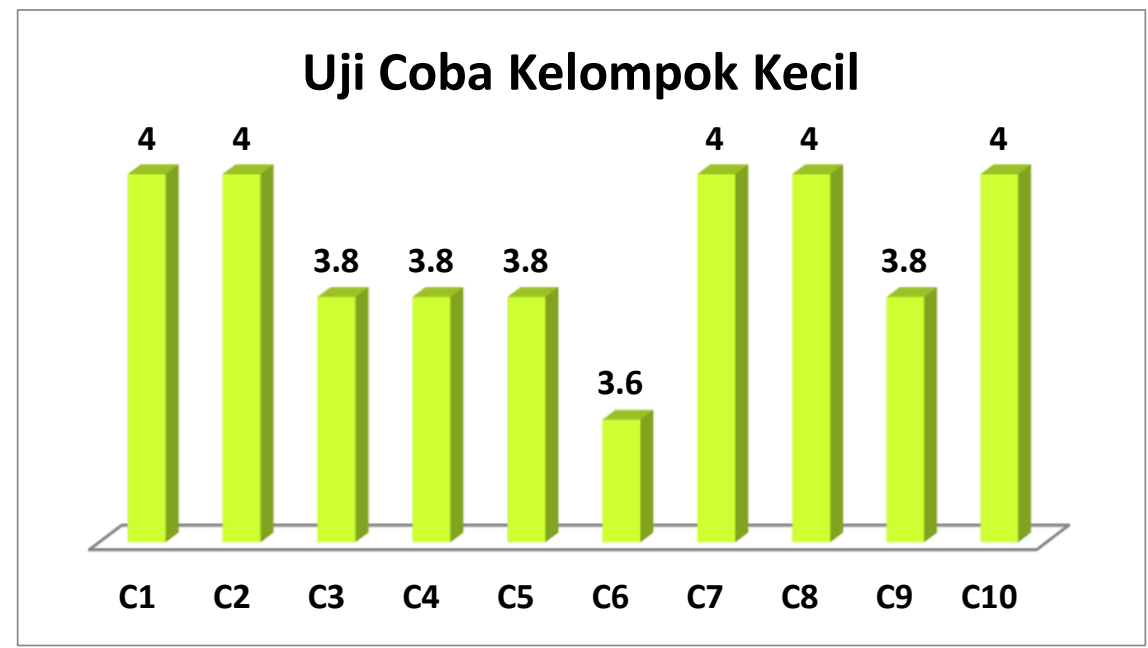

Gambar 5. Hasil Uji Coba Kelompok Kecil 


\section{PEMBAHASAN}

Penggunaan multimedia drill and practice untuk meningkatkan vocabulary bahasa Jepang ini memiliki beberapa kelebihan dan juga kelemahan. Pengembangan ini diujikan validitasnya ke Ahli Materi dan Ahli media Ada 15 aspek pernyataan yang berkenaan dengan materi yang terdapat dalam multimedia drill and practice. Pada angket Ahli Media dalam skala 1-4, Ahli media memberikan nilai 4 pada QC 1, QC 3-QC 6, QC 8-QC 9 yaitu pada aspek fungsi dan pemanfaatan media dalam memperjelas dan mempermudah penyampaian pesan, pada aspek tipografi yaitu pemilihan dan ketepatan teks, aspek bahasa dan pada aspek visual yaitu kemenarikan warna, background, kesesuaian dan kejelasan gambar, serta ritme dan kejelasan audio pada materi. Pada angket Ahli Media juga terdapat catatan dari Ahli Media yaitu secara umum cukup baik. Namun perlu ditambah beberapa audio pada tampilan awal dan perlu ditambahkan kalimat penguatan pada produk multimedia drill and practice agar lebih menarik.

Pada angket Ahli Materi di dalam skala 1-4, Ahli memberikan nilai 4 di QC 1-QC 3, QC 6-QC 7, QC 9-QC 15 yaitu pada aspek keakuratan materi konsep dan definisi, data dan fakta, contoh dan kasus, gambar dan petunjuk penggunaan kemudian pada aspek koherensi dan keruntutan materi, dan kesesuaian penggunaan waktu mengerjakan soal, dan pada aspek kemutakhiran materi yaitu kesesuaian materi dengan ilmu pengetahuan, ilustrasi kehidupan sehari-hari, dan kesesuaian hasil atau penilaian. Pada angket Ahli Materi juga terdapat catatan dari Ahli Materi yaitu secara umum materi pada multimedia sudah menarik dan mudah dimengerti, hanya ada beberapa perbaikan pada penggunaan huruf bahasa Jepang yaitu Ohayou dan Konnichiwa.

Pada angket uji coba terdapat 10 aspek pertanyaan diperoleh rata-rata keseluruhan jawaban audien berjumlah 3,88 dari total rata-rata jawaban yang diharapkan 4 yakni pada aspek pertanyaan : Mengenai tampilan multimedia drill and practice, kemenarikan warna dalam multimedia drill and practice, teks pada multimedia mudah dibaca atau tidak, kemenarikan font, kejelasan audio, keterpaduan antar gambar, teks,audio, kejelasan soal evaluasi materi, dan apakah pengguna lebih mudah mengerti setelah belajar bahasa Jepang menggunakan multimedia drill and practice. Berdasarkan hasil uji coba secara keseluruhan siswa dapat dengan mudah mengoperasikan muitimedia drill and practice dan mampu mengerjakan latihan soal yang disajikan dengan baik, namun ada beberapa siswa yang merasa kesulitan saat mengerjakan latihan soal dan perlu dibimbing oleh guru. hasil uji coba diperoleh hasil sebesar 3,88. berdasarkan kriteria yang telah ditetapkan dapat dijelaskan bahwa pengembangan multimedia dril and practice bahasa Jepang termasuk dalam kriteria valid. Pembelajaran melalui multimedia drill and practice telah terbukti secara nyata dapat meningkatkan kemampuan kosakata dan pemahaman pengguna. Performa pengguna meningkat karena pengguna merasa multimedia drill and practice bahasa Jepang mudah untuk digunakan.

Secara sederhana metode pembelajaran drill and practice dapat terbukti meningkatkan keaktifan belajar serta prestasi hasil belajar pada siswa. Penelitian dikatakan berhasil karena melalui aspek keaktifan, kognitif, serta afektif yang telah diukur sudah mencapai target. Metode pembelajaran drill and practice membuat siswa aktif untuk terus berlatih mengerjakan soal-soal latihan, berdiskusi, dan aktif bertanya, penggunaan multimedia drill and practice mampu membantu siswa dalam memahami materi (Nugroho et al., 2014). Yang membedakan dari pengembangan multimedia drill and practice bahasa Jepang adalah tidak adanya siswa aktif berdiskusi dikarenakan pengembangan ini untuk pembelajaran individu.

Penggunaan multimedia drill and practice merupakan salah satu alternatif agar dapat meningkatkan kemampuan vocabulary pada pengguna dalam pembelajaran bahasa Jepang. Hasil penelitian dari (Candra, 2014) memberikan hasil bahwa pembelajaran drill and practice adalah proses latihan berulang hingga tercapainya tujuan, sedangkan praktik memberikan pengalaman. Jadi proses belajar yang sebenarnya bersifat kompleks karena terjadi secara berulang-ulang. Menyajikan berbagai 
latihan-latihan soal dan jawaban serta umpan balik sebagai pembetulan. Dalam hal ini sesuai dengan penelitian pengembangan drill and practice bahasa Jepang yang dilakukan.

Dalam sistem pembelajaran bahasa mendukung para guru dalam memperkenalkan drill and practice untuk beberapa topik yang akan ditampilkan. Tetapi guru masih juga membutuhkan kemampuan penggunaan komputer dalam mengoperasikan multimedia drill and practice yang kemudian akan diajarkan pada siswa. Sistem penerjemah akan menerjemahkan kosakata melalui media drill and practice (Hussein, 2015). Jadi, dari hasil penelitian tersebut secara sederhana penggunaan multimedia drill and practice sesuai dengan topik bahasa karena ditekankan pada penggunaan kosakata. Pada tahun yang sama juga ditemukan hasil penelitian yang menunjukkan perbedaan yang signifikan telah ditemukan pada pencapaian rata-rata siswa dalam mata pelajaran yang diajarkan menggunakan drill and practice. Kemampuan penggunaan drill and practice dalam pembelajaran yang lebih baik ditemukan pada siswa perempuan dibandingkan dengan siswa laki-laki (Ozofor, Ndidiamaka Mike, 2015). Dalam hal ini, ada perbedaan dengan penelitian pengembangan multimedia drill and practice bahasa Jepang yang telah dikembangkan. Karena semua gender dalam ujicoba baik perempuan maupun siswa laki-laki menunjukkan perkembangan kemampuan yang baik selama menggunakan multimedia drill and practice.

Multimedia sendiri dapat menjadi pemecah masalah yang akan membantu siswa untuk membuat proses pembelajaran lebih interaktif. Kemudian dilakukannya penelitian terhadap multimedia drill and practice sebagai pemecah masalah. Dengan demikian hasil yang didapatkan menyatakan multimedia drill and practice pada mata kuliah layak, praktis dan efek potensial dengan kategori tinggi (Novita \& Burhan, 2016). Pernyataan tersebut sejalan dengan pengembangan multimedia drill and practice untuk mrningkatkan kemampuan kosakata bahasa Jepang pada siswa.

Pada software Drill and practice memberikan latihan dimana siswa mengerjakan contoh soal, dan kemudian menerima umpan balik pada jawaban yang benar. Siswa juga menyarankan drill and practice dan pemecahan masalah sebagai cara untuk membantu siswa dalam belajar. Isi dalam drill and practice serta umpan balik dianggap bervariasi sehingga memberi tanggapan yang baik dari siswa. Selain itu, para responden. Tujuan dilakukannya penelitian tersebut adalah menentukan perbedaan antara pembelajaran menggunakan metode tradisional dengan metode modern seperti penggunaan drill and practice (Pacol \& Patacsil, 2018). Dari hasil tersebut ditemukan perbedaan yaitu dalam penelitian pengembangan multimedia drill and practice bahasa Jepang yang difokuskan pada keefektifan produk dan hasil belajar siswa selama menggunakan multimedia drill and practice, bukan pada metode pembelajaran modern atau tradisional saja.

Metode pembelajaran drill and practice merupakan suatu pendekatan pembelajaran menggunakan latihan yang komprehensif dalam mendapatkan keterampilan tertentu (Vita FS, Mayar Afriyenti, 2019). Metode pembelajaran drill and practice dapat dijadikan suatu alternatif dalam proses pembelajaran. Dari penelitian tersebut, yang membedakan yaitu penelitian kali ini merupakan pengembangan produk berupa multimedia drill and practice bertujuan untuk meningkatkan kosakata bahasa Jepang pengguna.

Berbagai metode secara sederhana penggunaannya harus disesuaikan dengan tujuan pembelajaran, fasilitas serta kemampuan untuk menerapkan metode itu sendiri. Salah satu metode yang tepat dalam mengoperasikan komputer adalah drill and practice (Watini et al., 2020). Metode ini bertujuan untuk meningkatkan keterampilan dan memperkuat penguasaan konsep serta efektif juga efisien.

\section{SIMPULAN}

Multimedia drill and practice merupakan solusi untuk memberikan kemudahan dalam menigkatkan kemampuan vocabulary pada bahasa Jepang. Multimedia drill and practice ini memiliki kelebihan yang mana pengguna bisa, dapat mengurangi biaya,. Dalam Penilaian Ahli Materi multimedia drill and practice dikatakan valid dan layak digunakan. Dalam Penilaian Ahli Media multimedia drill 
and practic dikatakan valid dan layak untuk digunakan. Hanya ada kekurangan dengan saran perbaikan oleh ahli media yaitu pada multimedia drill and practice sebaiknya diberi audio di awal tampilan. Dalam uji coba kelompok kecil diperoleh hasil valid dan layak digunakan. Multimedia drill and practice ini memiliki beberapa kelebihan dalam menyampaikan matri yang menarik dalam bntuk latihan soal atau kuis. Sehingga multimedia drill and practice ini mampu menghantarkan pesan kepada pengguna agar mempermudah mempelajari bahasa Jepang dan meningkatkan kemampuan kosakata pengguna.

\section{DAFTAR RUJUKAN}

Adiwisastra, M. F. (2015). Perancangan Game Kuis Interaktif Sebagai Multimedia Pembelajaran Drill and practice Untuk Meningkatkan Hasil Belajar Siswa. II(1), 205-211.

Ampuch, A., Hiranrat, W., Pimbaotham, N., \& Singnan, T. (2014). Developing a Computer Assisted Instruction with Drill and practice for English Teaching to Primary School Grade 6 Students with Hearing Impaired. 22(2), 47-53.

Ariani, Niken. \& Haryanto. (2010). Pembelajaran Multimedia di Sekolah. Prestasi Pustaka.

Binanto, I. (2010). Multimedi Digital - Dasar Teori dan Pengembangannya (H. F. Andi. Demanik, J \& Weber (ed.)).

Candra, B. S. (2014). Penerapan Model Pembelajaran Drill and practice Terhadap Hasil Belajar Chest Pass Pada Permainan Bola Basket Studi Pada Siswa Kelas X SMA Negeri 1 Kota Mojokerto. FIK UNESA.

Dale \&Edgar. (1969). Audiovisual Method in Teaching. Third Edition. The. Dryden Press, Holt, Rinehart and Winston, Inc.

Dimyati \& Mujiono. (2009). Belajar dan Pembelajaran (Pfeiffer (ed.)). PT Rineka Rosdakarya.

Educatio, J. (2014). Pengembangan Paket Pembelajaran Bahasa Indonesia Berbasis Drill and practice Melalui Model Pembelajaran Berbantuan Komputer : Analisis Kebutuhan Di Sma / Ma. 9(2), 278292.

Hussein, K. Q. (2015). A Uthoring System Of Drill \& Practice E-Learning Modules For Hearing Impaired Students. 7(1), 131-138. https://doi.org/10.5121/ijcsit.2015.7113

Lee. W. W \& Owens. (2004). Multimedia-Based Instructional Design. (2nd Ed). Pfeiffer.

Mayer. (2009). Multimedia Learning. Pustaka Belajar.

Novita, E. W., \& Burhan, A. (2016). Pengembangan Multimedia Interaktif Model Drill and practice Pada Mata Kuliah Pengukuran Teknik Di Program Studi Pendidikan Teknik Mesin Universitas Sriwijaya. 3(1), 9-17.

Nugroho, S. A., Redjeki, T., \& Mulyani, S. (2014). Penerapan Metode Drill and practice Dilengkapi Belajar Pada Materi Pokok Hidrolisis Garam Kelas Xi Ipa 5 Sma Negeri 7 Surakarta Tahun Pelajaran 2012 / 2013. 3(4), 93-99.

Ozofor, Ndidiamaka Mike, P. . D. ( N. ) D. of M. / C. S. (2015). Effect Of Two Modes Of Computer Aided Instruction On Students' Achievement And Interest In Statistics And Probability. 3(1), 89102.

Pacol, C. A., \& Patacsil, F. (2018). Drill and practice Courseware in IT Fundamentals. 2(2), 1-11. https://doi.org/10.26666/rmp.ajtve.2018.2.1

Ramadhan, R., Si, M., Amelia, R., \& Kom, M. (2015). Penerapan Metode Pembelajaran Drill And Pratice Berbasis Multimedia Terhadap Hasil Belajar Pada Mata Pelajaran TIK Kelas VII SMP Kartika 1-6 Padang.

Rusman. (2011). Pembelajaran Berbasis Teknologi Informasi dan Komunikasi. Rajawali Pers.

Rusman. (2012). Belajar dan Pembelajaran Berbasis Komputer. Afabeta. 
Smaldino, S.E., Lowther D.L., \& Rusell, J. . (2011). Instructional Technology \& Media for Learning. Kencana.

Undang-Undang Republik Indonesia. (1989). Undang-Undang Republik Indonesia. In Undang-Undang Republik Indonesia. Citra Umbara.

Vita FS, Mayar Afriyenti, A. E. (2019). Drill and practice Sebagai Metode Pembelajaran Alternatif Untuk Mata Pelajaran Pratikum Akuntansi Manufaktur di Sekolah Menengah Kejuruan. 7(2), $1541-1550$.

Watini, S., Childhood, E., Education, T., Program, S., \& Tasikmalaya, U. M. (2020). ICT Competency with Drill and practice Method in Making Multimedia Visual Learning. 13(2), 889-893.

Widodo, S., \& Pd, M. (2017). Pengaruh Metode Pembelajaran Drill and practice Didukung Media Dua Dimensi Terhadap Kemampuan Menghitung Keliling Bangun Datar Persegi Dan Persegi Panjang Siswa Kelas Iii Semester Ii Sdn Pare 2 Tahun Ajaran 2016 / 2017. 01(06). 